міжнародної наук.-практ. конференції (16-17 травня 2019, м. Вінниця). Вінниця: ТОВ «Твори», 2019. Т. 1. С. 195-197.

5. Чижкова М. Б. Комуникативная компетентность врача и ее формирование в представлениях ординаторов: к постановке проблемы. Современные проблемы науки и образования. 2020. № 2. URL: http://science-education.ru/ru/article/view?id=29727

DOI https://doi.org/10.30525/978-9934-588-80-8-1.3

\title{
МОЖЛИВОСТІ ДЛЯ ФОРМУВАННЯ МОЛОДОГО НАУКОВЦЯ ПІД ЧАС НАВЧАННЯ В УНІВЕРСИТЕТІ
}

\author{
Басюга I. O. \\ кандидат медичних наук, \\ доцент кафедри акушерства і гінекології імені І. Д. Ланового \\ Івано-Франківський начіональний медичний університет \\ Костіцька I. O. \\ доктор медичних наук, \\ професор кафедри ендокринології \\ Івано-Франківський начіональний медичний університет \\ Матвійків Н. I. \\ кандидат медичних наук, \\ асистент кафедри акушерства і гінекології ПО \\ Івано-Франківський начіональний медичний університет \\ м. Івано-Франківськ, Украӥна
}

Основні завдання та вимоги щодо професійної діяльності сучасних фахівців $є$ достатньо високі, вимагають від викладача забезпечити майбутнього фахівця базовою інформацією, розвинути у нього навички та уміння для розв'язання конкретних завдань. Впровадження та застосування інформаційних технологій (IT) дозволяе підвищити якість освіти, підібрати індивідуальні засоби засвоєння знань шляхом самостійної роботи, формування вміння самостійно здобувати знання $\mathrm{i}$ вести дослідницьку діяльність[1, 2 с. 132].

Для студентів, які бажають отримати глибші знання, детально вивчити окремі нозоології, з можливістю проведення самостійного науково-дослідного вивчення, на кафедрах університету функціонують студентські наукові гуртки. Активна участь студентів в науково- 
дослідній роботі $є$ ефективним засобом підвищенням якості підготовки фахівців, розвитку їх соціально-психологічної компетентності для роботи у професійних колективах [3 с. 68,4 с. 265,5 с. 104]. Основним видом діяльності студентського наукового гуртка $\epsilon$ виконання студентами в позааудиторний час наукових досліджень за напрямками, які вивчає кафедра. Вибір теми наукового дослідження студента, а в подальшому лікаря і молодого науковця, $\epsilon$ важливим моментом, оскільки часто вона на довгі роки визначає напрям наукових та клінічних інтересів. Студент обирає для себе коло питань, якими він зацікавився, а науковий керівник, яким є викладач кафедри, допомагає у виборі теми дослідження. Підготовка тез, виступів та презентацій на конференціях дають безцінний досвід, який в майбутньому допоможе здобути навики комунікації, формуванню особистості науковця, дозволить проводити просвітницьку роботу серед різних колективів чи шляхом публікацій, виступів у засобах масової інформації.

Підготовка і формування особистості лікаря за участі науковопедагогічних працівників дозволяе активізувати навчально-виховний процес, сприяє професійному зростанню та підвищує рівень підготовки майбутніх фахівців.

\section{Література:}

1. Національна доповідь про стан і перспективи розвитку освіти в Україні. Нац. акад. пед. наук України; за заг. ред. В. Кремнія. Педагогічна думка. 2016. С. 448.

2. Мороховець Н.Ю. Формування інформаційного освітнього середовища вищого медичного закладу освіти. Вісник Чернігівського педагогічного ун-ту ім. Т.Г. Шевченка. 2016. № 136. С. 132-135.

3. Рожко М.М., Єрстенюк Г.М. Капечук В.В., Івасів М.О. Освітній процес і система управління якістю освіти в підготовці медичних фахівців. Медична освіта. 2017. № 3. С. 68-71.

4. Ленкова О.О., Мороховець Н.Ю., Міщенко С.В. Формування інформаційно-комунікаційних компетенцій майбутніх лікарів на засадах використання комп'ютерних технологій в навчальному процесі. Актуальні проблеми сучасної медицини. 2015. № 15 (3). С. 264-269.

5. Чережова I.О. Комунікативна компетентність як інтегральна якість особистості. Науковий вісник Херсонського державного університету. Серія: Психологічні науки. 2014. № 1 (1). С. 103-107. 